EDITORIAL

https: / /doi.org/10.22239/2317-269x.01987

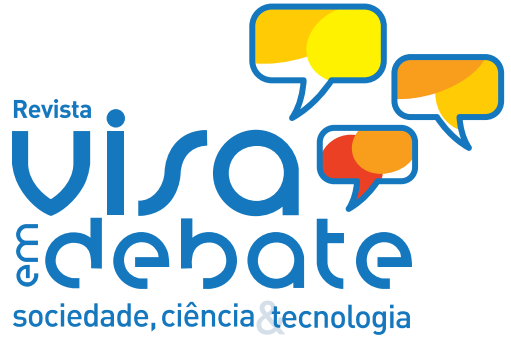

sociedade, ciência tecnologia

\title{
A proteção da saúde em perigo, em plena pandemia
}

\section{Geraldo Lucchese* (ID)}

Grupo Temático de Vigilância Sanitária (GTVISA), Associação Brasileira de Saúde Coletiva (Abrasco), Rio de Janeiro, RJ, Brasil
Nestes tempos de pandemia, o Sistema Único de Saúde (SUS) foi reconhecido e elogiado por aquela parcela da sociedade que não o valorizava como uma política pública emancipadora, civilizadora, humanista e de justiça social. Parte importante do trabalho do SUS, que o fez reconhecido e valorizado, foi feita pela Vigilância Sanitária (Visa). Desde a análise e aprovação de pesquisas clínicas de vacinas; a autorização para seu uso emergencial; a flexibilização normativa visando a produção ou importação acelerada de álcool em gel, kits diagnósticos e outros insumos e a orientação para a organização dos serviços de saúde; até a orientação ao comércio em geral; a atuação em barreiras sanitárias e a fiscalização de serviços no cumprimento das medidas sanitárias adotadas em cada município ou região. Mesmo outras instâncias do próprio SUS perceberam de forma mais clara o papel da Visa para o sistema e para a sociedade. Entretanto, não obstante o reconhecimento de sua imensa importância para os brasileiros, o SUS enfrenta sérias ameaças. Desde 2015, com o início do Governo Temer, setores do mercado da saúde, com o velho e falso argumento da maior competência dos serviços privados, estão propondo a hibridização do SUS. Querem até mesmo operar na Atenção Primária, nas equipes de saúde da família, um dos pilares essenciais do sistema e o de maior contato com a população local. Isso significa a drenagem de recursos da saúde para as empresas particulares que, mesmo que falem o contrário, não têm o compromisso social necessário ao fortalecimento do SUS e a visão da determinação social da saúde. Sabemos que nenhum dos grandes problemas do país será resolvido pela lógica do mercado que, infelizmente, é hegemônica e convence até os mais humildes de que ela é a saída. As ameaças ao SUS público, universal e gratuito significam, necessariamente, ameaças à Visa e ao seu trabalho de proteção da saúde. $O$ anseio neoliberal é um Estado frágil, que praticamente não tem estrutura e poder para intervir no mercado privado, em qualquer área. Por isso a proibição de se aumentar o teto de gastos. $O$ objetivo é sucatear qualquer serviço público e justificar sua extinção ou privatização. Há tempos não temos, por exemplo, concursos para o trabalho na Visa. E os trabalhadores da Visa têm consciência de que são parte do SUS, universal, público e gratuito. E que trabalham para concretizar o direito social à saúde. Sabem que seu trabalho está voltado a proteger a saúde das outras pessoas, com o cuidado do outro. Sabem que o SUS, e a Visa dentro dele, é diferente do modelo de mercado, no qual quem tem dinheiro compra a proteção à sua saúde. 0 objetivo principal desta Revista é estimular a produção de estudos e pesquisas e divulgá-los a todos os interessados, de forma aberta e pública. Entretanto, o fomento à pesquisa, ao desenvolvimento e à inovação é outra área imensamente prejudicada pela política governamental. Os recursos para pesquisa nas universidades públicas, a principal fonte de produção de conhecimentos no Brasil, foram, também, imensamente reduzidos. O negacionismo científico propalado pelo Governo Federal condena o Brasil, um país com recursos valiosos e estratégicos, ao papel de um produtor primário, fornecedor eterno de matérias primas. Apesar desse contexto, resistimos e estamos aqui com mais um número, que traz artigos de grande importância para a saúde pública brasileira, como a relação entre a Visa e a Atenção Primária, o controle de qualidade dos testes rápidos para o diagnóstico da COVID-19, a regulação de preços de medicamentos, a gestão da qualidade, o registro de medicamentos, a avaliação de mosquitos modificados para o controle de arboviroses, a contaminação em diferentes alimentos de alto consumo e cantinas escolares saudáveis, entre outros. Nosso propósito de fundo é a proteção à saúde dos brasileiros, a qualificação dos serviços prestados pelo SUS e seu fortalecimento, com vistas a concretizar o direito social à saúde previsto na Constituição Federal. Por isso, o Brasil precisa do SUS e o SUS precisa da Visa.

* E-mail: visaemdebate@incqs. fiocruz.br 